\title{
WHATEVER KIND OF PAGAN THE BEARER MIGHT BE, THE LETTER IS VALID. A SKETCH OF CATHOLIC- ORTHODOX RELATIONS IN THE LATE-MEDIAEVAL GRAND DUCHY OF LITHUANIA
}

\author{
S.C. Rowell
}

\begin{abstract}
This article examines relationships between Catholic and Orthodox Christians in the Grand Duchy of Lithuania at the turn of the fifteenth and sixteenth centuries. It stresses the robust policies of Catholic and Orthodox prelates and nobles towards one another and especially towards the Unionist Ruthenians, who sought to maintain their liturgical and hierarchical identity while recognising the primacy of the bishop of Rome. By contrast in personal situations Catholics and Orthodox were willing to cooperate on practical matters (usually concerning family property or community business). In Vilnius victories over national enemies (Tatar or Muscovite) were celebrated in monumental architecture by both communities. Evidence from consistory courts in Lutsk and Gniezno, and ecclesiastical emoluments in the Diocese of Vilnius reveal cooperation between both communities at a family and parish level could exist.
\end{abstract}

There may be conflicting views of relations between Catholic and Orthodox subjects of the Grand Duchy of Lithuania in the first century or so after the baptism of pagan Lithuanians in the Roman rite. These views of apartheid, opposition and mutual imitation are confused further by the existence of the Unionists, whom neither Orthodox nor Latin-rite Catholics much loved. Since the Reformation and Counter-Reformation maintaining officially sharp distinctions between all three groups in the battle to establish self-evident purity of belief prejudges how we might imagine mediaeval inter-confessional relations to have functioned and makes multi-confessional Vilnius in the seventeenth century appear more curious than it is. ${ }^{1}$ It may be helpful to examine the question at the levels of macro- and micro-history where mutual antagonism and apartheid are softened

${ }^{1}$ D. Frick, Kith, kin and neighbors: Communities and confessions in seventeenthcentury Wilno (Ithaca NY, 2013). 
somewhat by the importance of kinship ties, cultural imitation and what we might term, to adapt a phrase from literary criticism, a suspension of misbelief, whereby a person might accept that following a different confession be unconscionable but still favour a particular sectary for private reasons (usually associated with kinship or property, or both).

In 1501 a Lithuanian embassy to Pope Alexander VI sought, among other things, advice on how to deal with Orthodox Christians wishing to unite with the Roman Church. The mission was sent by the reformer bishop of Vilnius, Albert Tabor, and it was just a part of his attempts to clarify episcopal control over and enrich the ecclesiastical province of Vilnius. It was also relevant to political life within the Grand Duchy, whose ruler, also Alexander, was married to a Russian Orthodox duchess, Elena, daughter of Ivan III of Moscow. That same year a delegation was sent to Vilnius by Grand Duke Alexander's brother, King John Albert of Poland. The embassy orator was a Cracow university divine, Jan Sakran of Oświęcim, who had been an intellectual idol of the young student Albert Tabor some three decades earlier. He had made a name for himself in disputations with the Bernardine friars of Cracow, who, like their Vilnius brethren, were involved closely in missions to the Orthodox and whose stance on the issue of whether Orthodox converts should be forced to undergo a second baptism (that they should not) was approved by Rome and resisted vehemently by Polish and Lithuanian bishops. Tabor asked Sakran to compose a treatise elucidating the errors of the Ruthenian rite: Elucidarius errorum ritus Ruthenici. This would be published in Cracow in 1501 and undergo several reprints in an abbreviated version, on the errors of the most atrocious Ruthenians, in Cologne during the first decade of the sixteenth century ${ }^{2}$. Sakran accepted the commission, while complaining that he was unable to consult his books and that any errors he made himself would be

2 Jan Sakran of Oświęcim (1443-1527), Elucidarius errorum ritus Ruthenici (Cracow, 1501) [Vienna, Austrian National Library 7.V.55]. The treatise was summarised in forty brief chapters in an edition published by Martin von Werden in Cologne in 1508, Errores atrocissimorum Ruthenorum. Ex tractatu domini Joannis Sacrani sacre Theologie magistri et Cracoviensis ecclesie quondam canonici, quem intitulavit Elucidarium errorum ritus Ruthenici et inscripsit Reverendo in Christo patri domino Alberto episcopo Vilnensi. For bibliographical details see D. Narbutienè, S. Narbutas, XV-XVI a. Lietuvos lotynišku knygų sąrašas (Vilnius, 2002), nos 275-280, pp. 170-172. 
acknowledged as such and subject to papal correction ${ }^{3}$. He knew he was writing a tendentious tract dedicated to the bishop 'presiding most vigilantly in the Lithuanian see of Vilnius, surrounded, like a lamb among rapacious wolves, by a tumultuous band of Ruthenians most dangerous foes of your Church and that of Rome' ${ }^{4}$. Sakran tells the story of an Orthodox Lithuanian courtier, Alexander Soltan, who with his brother Iwaszko sought to confirm their social standing in the Vilnius hierarchy by becoming Catholics. Alexander travelled to the curia and was received into the Roman rite by Pope Paul II in 1471 who gave him Communion albeit without renewed baptism and without, it is stated, documents to confirm Soltan's repudiation of his Greek errors. On his return to Vilnius Soltan attempted to receive communion in Vilnius cathedral, where he was denounced 'unadvisedly' as a dog 5 . Orthodox Christians were not permitted to enter the cathedral normally let alone take Communion there. This treatment of the marshall strengthened the resolve of other Orthodox not to accept Roman jurisdiction. On his deathbed Soltan asked to be taken to the Bernardine church, but apparently his wish was thwarted by some of his Orthodox servants. According to Sakran's version of events, Soltan was received by Sixtus IV (who succeeded Paul II in 1471) as a Unionist and given bulls to that effect but returned to Lithuania as an enemy of the Church and a blasphemer. In effect the courtier acknowledged the supremacy of the pope and received Communion in Rome but his conversion was not accepted by leading members of Vilnius Catholic society. Another example of a Lithuanian Unionist misrepresented by Sakran is Jonas Sapiega, the scribe of Grand Duke Alexander whose approach to Rome in 1501 is regaled by our ideologue, which implies that Sapiega was

${ }^{3}$ Hec itaque, dive pontifex Alberte, pro te utcunque corrogata bona et amica mente suscipe quedam me in externo solo versatum absque librorum supellectili necessaria in hac materia resolute dicere nil potuisse..., - Elucidarius, fo xxxiiii.

${ }^{4}$ Elucidarius, fo ii: Celebri ac reverendo in Christo patri et domino, domino Alberto Dei gratia episcopo Vilnensi, patri summa veneratione digne colendo Joannes Sacranus indignus sacre Theologie magister Cracoviensis ecclesie canonicus debitam obedientiam. Presul inclite et Deo dicate antistes, qui in Lithuania Vilnensi sedi vigilantissime presidens tumulatuante turba Ruthenorum tue Romaneque Ecclesie infensissimorum hostium circumseptus, velud agnus inter rapaces lupos, a virid doctis salutare semper subsequeris et expectas...

${ }^{5}$ According to Ciołek's annotation to the mission documents - S. Kutrzeba, J. Fijałek, 'Kopiarz rzymski Erazma Ciołka z początku wieku XVI', Archiwum Komisji Historycznej 1 (13) (1923), p. 77. 
commanded to take Catholic holy orders when he sought to express his obedience to Rome but failed to do so ${ }^{6}$.

The main theological differences between the Ruthenians and Catholics were the same as ever: the provenance of the Holy Ghost from Father and Son, which had been reconciled in Florence; the Orthodox practice of baptism by immersion (Sakran alleges that Russians baptize with vinegar and liquids other than water; he condemns their use of leavened bread in the Orthodox Divine Liturgy; the Orthodox are accused of not recognising second or third marriages and denying the sacrament of the sick. Papal supremacy was another stumbling block. The problem of demanding the rebaptism of Orthodox seeking union with Rome boiled down in effect to a denial of the efficacy of all the Orthodox sacraments. In practice this forces possible converts to acknowledge publicly that all their religious life thitherto had been a great error. We cannot understimate the significance of public ceremonial. Appearance and public actions were essential to mediaeval (and probably are to all) societies. Unable to take part in public religious rites in Vilnius cathedral marked Orthodox Christians visibly as less prestigious than Catholics. Names too, given at baptism, are an intimate part of a person's identity. Perhaps some Catholic nobles had undergone this after 1385 - Gostautas for example was known in the earliest Latin records as Iwan and only later becomes Johannes. Baptism is a public and social sacrament which creates new ties of kinship. Rebaptism surely more than hints at a breaking of ties created by the first initiation into the Christian community.

Sakran and by extension Tabor was flying close to the wind with this critique of Orthodoxy. Sakran contested the right of the pope to object to second baptism, since the Russian rite was clearly corrupt in itself, since apparently any liquid, including fermented apple juice, was used in their baptism ceremony, and although the pope enjoys fullness of power in matters of sacramentals, God alone has the power to create sacraments. The pope cannot make something which is not a sacrament a sacrament. To cover his back Sakran

${ }^{6}$ Dominus Alexander papa sextus Rutheno quodem ex Lithuania dicto Sopia scriba magni ducis Lithuanie ad obedientiam accedente et petente se conservare circa ritum patrium deferente coram presbiteris sui ritus secum habitum ritum quidem duraturo sub obedientia dissimulantur indulsit, sed illum precepit et denuo fecit ad sacerdocium ordinari et de ritu exanimari ac eius errata castigari unde preceptis pape non solum in certis sed etiam in dubiis operum obedire, - Elucidarius, fo xxi. 
cites Petrus de Palude, the fourteenth-century French Dominican and Latin patriarch of Jeruslaem. Having sparred with Alexander VI Sakran indirectly takes on Grand Duke Alexander of Lithuania, noting that a Catholic may not marry a Schismatic even in the hope of bringing about her Catholic baptism.

Sacran presents Lithuanian history through a particular sectarian prism - Lithuania was brought to Catholicism by Vytautas and that same Vytautas oversaw the baptism of many pagans in a single day by aspersion or affusion (the Roman way) rather than immersion (the Greek way), thereby implicitly legitimising the Latin rite as theologically correct and historically Lithuanian. Sakran fails to mention that Vytautas opposed the rebaptism of his Orthodox subjects, an act which he (or at least his advisers) regarded as an insult to the Sacrament itself ${ }^{7}$. The stories of Soltan and Sapiega are told from a clearly recognisable but misleading point of view. He also depicts Ruthenian practices in a distorted (and sometimes deliberately false) way. Thus baptism is said to be effected with fermented apple juice and the description of the Orthodox Eucharist is described in great detail with a false interpretation. Thus we are given an account of the prosphora and Panagia, the Orthodox leavened bread which is consecrated for Holy Communion. In Ruthenian tradition there are five prosphora, triangular pieces of holy bread solemnly blessed, but not consecrated like the Lamb or Host, during Divine Liturgy in honour of the Mother of God (the Panagia) and among others, the Nine Ranks of Saints, which include St John the Baptist, the Prophets and so on. Sakran tells us that these particles of holy bread are consecrated as the Body of Our Lady, St John the Baptist, Basil, Leo, Elijah and so on. They apparently use wooden vessels (chalices and spoons) for the Sacrament, a practice which is forbidden by the Roman Church (or at least any wooden chalice should be lined suitably with precious metal). This is shocking for a Catholic reader (as Sakran intends) but the details are not drawn from the author's imagination; the latter is merely the source of his interpretation of Orthodox practice.

7 In 1417 Vytautas and Jogaila appealed to the Fathers of the Council of Constance not to require the Orthodox to undergo a second baptism: hoc modo iniuria fieret sacramento... grande eisdem Ruthenis... reducentis prestatur ostaculum, - 25 Aug. 1417, Copiale prioratus Sancti-Andree. The Letter-book of James Haldenstone Prior of St. Andrews (1418-1443), ed. J.H. Baxter (Oxford, 1930), no. 20 , pp. $38-41$. 
Much ink has been spilled in discussion of the early history of ecclesiastical union in Lithuania, the sources for which are few and far between and have been known to scholarship for several generations ${ }^{8}$. The question of uniting the Roman and Greek Churches on the territory of the Jagiellonian Monarchy was relevant from the official Latin conversion of 1387 if not earlier. In 1395-1396 Jogaila and Vytautas were urging the patriarch of Constantinople to discuss the issue, and the steppe campaigns of the two statesmen in 1397-1399 can be seen as part of collaboration with Sigismund of Hungary to come to the military aid of Byzantium. Plans were made in Lithuania to implement the Union agreed at FerraraFlorence in 1439 involving the Lithuanian cardinal, Metropolitan Isidore of Kiev. The latinisation of the Orthodox Church in the Grand Duchy would have extended the network of parish churches across the Grand Duchy with more speed than reliance on founding new separate Catholic churches could afford. The Franciscans Conventual and the Dominicans worked to this end especially in the more southern territories; in Vilnius and Kiev this mission was entrusted to the Bernardines and extended at the end of the fifteenth century to more far-flung parts of the realm (Polotsk in the north east, Tykocin in the south west).

The complex divisions in eastern Orthodoxy in Rus' with regard to relations with Rome have been underlined by recent research on Metropolitan Spiridon Savva of Kiev and All Rus' from the pen of V.I. Ul'ianovskii ${ }^{9}$. In effect it reinforces the impression gained from most sources that a metropolitan of Lithuania was unpopular with the grand duke of Muscovy for being potentially harmful to eastern Rus'ian interests and with the ruler(s) of Lithuania and Poland for not being a Unionist. Ul'ianovskii has used hitherto incompletely understood Graecisms in texts by this monk from Tver' to re-date Spiridon's appointment and consecration as metropolitan

${ }^{8}$ The basic account remains O. Halecki, From Florence to Brest (1439-1596) (Rome, 1958); A recent Polish translation: Od Unii Florenckiej do Unii Brzeskiej, tr. A. Nikiewicz, 2 vols (Lublin-Rome, 1997). See also the more recent study: B.A. Gudziak, Crisis and Reform. The Kyivan Metropolitanate, the Patriarchate of Constantinople and the Genesis of the Union of Brest (Cambridge MA, 1998).

${ }^{9}$ A.I. Alekseev, "'Spiridon rekomyi, Savva glagolemyi” (zametki o sochineniakh kievskogo mitropolita Spiridona)', Drevniaia Rus'. Voprosy medievistiki, 41 (2010), pp. 5-15; V.I. Ul'ianovskii, Mitropolit kievskii Spiridon (Kiev, 2004); idem, 'Mitropolit kievskii Spiridon: iavye i skrytye povestvovania o sebe v sochineniach 1475-1503 gg.', Trudy otdela drevnerusskoi literatury (2006), pp. 209-233. 
to December 1474 (by Patriarch Simeon I of Trabizond, rather than Raphael) in succession to Metropolitan Grigorii Bolgarinovich, who died late in 1473. Casimir Jagiellonczyk and the Lithuanian Unionists did not push for the appointment of their own candidate Archimandrite Misael of Kiev by the Pope (Sixtus IV) until 1476, by which time the graecophile anti-Unionist Spiridon had earned the displeasure of the Jagiellonian monarch. In captivity in Punia Spiridon actively stressed his own Byzantine credentials (as vestitor of the Patriarch's Great Church in Constantinople, for example) and superior, almost Catholic titulature (he styled himself Ruthenian archbishop - arkhiepiskop riseiskii), preaching to the local Orthodox population on such controversial topics as the Procession of the Holy Ghost. In 1477 Bishop Vassian of Tver' warned Rus'ians not to deal with Spiridon or any other metropolitan of Kiev who had been appointed by the godless Turk or the Latins ${ }^{10}$. Orthodox culture thrived in Lithuanian-ruled Kiev. The Olelkovich princes employed Jewish scholars to produce Ruthenian (rather than Church-Slavonic or eastern Slavonic) vernacular translations of Holy Scripture and western and Arabic philosophical and scientific texts. ${ }^{11}$ It was in the midst of these arguments (in 1475) over what kind of Lithuanian metropolitanate and how it should relate to the Roman Church that the Bernardines of Vilnius obtained papal permission to admit Schismatics to their friary church since Ruthenian citizens of Vilnius came to Divine Office and Mass and ejecting them from the premises would give rise to scandal. The prohibition on admitting

${ }^{10}$ Ibid., especially pp. 214-223. See also A.A. Turilov, 'Zabytoe sochinenie mitropolita Savvy-Spiridona litovskogo perioda ego tvorchestva', Slaviane $i$ ikh sosedi 7 (1999), pp. 121-137. His name as metropolitan reminds us (as was intended) of St Spyridon of Trimithous, who defended the doctrine of the Holy Trinity at the Council of Nicaea in 325 .

${ }^{11}$ S.Yu. Temchin, 'Skharia i Skorina: ob istochnikakh vilenskogo vetkhozavetnogo svoda (F 19-262)', Senoji Lietuvos Literatūra, 21 (2006), pp. 289-314; S. Temčinas, 'Bažnytinès knygos rusėnų kalba ir religiniai identitetai slaviškose Lietuvos Didžiosios Kunigaikštijos žemėse XIV-XVIII a. Stačiatikių tradicija', Lietuvos Didžiosios Kunigaikšttijos tradicija ir paveldo "dalybos", ed. A. Bumblauskas et al. (Vilnius 2008), pp. 149-155; idem, 'Kirillicheskii rukopisnyi uchebnik drevneevreiskogo iazyka (XVI v.) i vilenskii vetkhozavednyi svod', Knygotyra, 57 (2011), pp. 86-99. M. Taube, 'The fifteenth-century Ruthenian translations from Hebrew and the Heresy of the Judaizers. Is there a connection?', Speculum Slaviae orientalis. Muscovy, Ruthenia and Lithuania in the Late Middle Ages, ed. V.V. Ivanov, J. Verkholantsev (Moscow, 2005), pp. 185-208. 
non-Catholics to Catholic churches was retained with regard to the secular churches, especially the cathedral ${ }^{12}$.

By the final decade of the fifteenth century the question of how to deal with the Orthodox took on even greater significance in the Grand Duchy. In 1494 Grand Duke Alexander married the Orthodox duchess of Muscovy, Elena Ivanovna ${ }^{13}$. Catholic noblemen built more and more parishes churches across the dioceses of Vilnius and Lutsk and the bishop of Vilnius, Albert Tabor became increasingly aware of the weakness of his control over religious life in his diocese ${ }^{14}$. $\mathrm{R}$. Černius is correct to note that the Union Question was taken up by inter-related noblemen with an interest in both Churches ${ }^{15}$. He notes that Jonas Sapiega was a kinsman of Metropolitan Iosif and both had connections with Smolensk. Sapiega was also an affine of the lord lieutenant of Polotsk, Stanislovas Hlebavičius. Both men were courtiers of Grand Duchess Elena and had landed and professional interests extending from Smolensk in the east via Vilnius and the Novgorodok area to Podlasie in the west. Both men were Catholics. Černius discerns two Union projects, one favoured by Metropolitan

${ }^{12}$ Kodeks dyplomatyczny katedry $i$ diecezji wileńskiej, [further: KDKDW] ed. J. Fijałek, W. Semkowicz, I (Cracow, 1948), no. 292, p. 340-341. In 1428 the Conventual Franciscans were granted permission by Martin V to maintain a lector to work with pagans and schismatics - no. 94, p. 122-123. For Lithuanian language studies of the Bernardine missions see V. Gidžiūnas, 'Pranciškonų observantųbernardinu gyvenimas ir veikla Lietuvoje XV ir XVI a.', Lietuvos kataliku moksly akademijos Suvažiavimo darbai 9 (1982), pp. 35-134; reprised in R.R. Trimoniené, 'Katalikų Bažnyčios politika bažnytinès unijos klausimu Kazimiero ir Aleksandro valdymo metais', ibid., 12 (1998), pp. 327-340.

${ }^{13}$ For most recent work, see M.E. Bychkova, 'Velikaia kniazhna Elena Ivanovna v Moskve i v Vil'no'; Lietuvos didysis kunigaikštis Aleksandras ir jo epocha. Moksliniu straipsniu rinkinys, ed. R. Petrauskas et al. (Vilnius, 2007), pp. 86-98, R. Ragauskienė, 'Lietuvos didžiosios kunigaikštienès Elenos (1476-1513) patronatas', ibid., pp. 99-110.

14 J. Ochmański, Biskupstwo wileńskie w średniowieczu. Ustrój i uposażenie (Poznań 1972), pp. 63-71; T. Jaszczołt, 'Fundacje kościelne na Podlasiu do końca XV wieku', Kościół a państwo na pograniczu polsko-litewsko-białoruskim. Źródta $i$ stan badań (Białystok, 2005), pp. 14-52; S.C. Rowell, 'Kaip šaukè, taip ir atsiliepė: XV a. lietuvių katalikų gyvenimas ir pagonybės liekanų mitas', Lietuvos Didžiosios kunigaikštystès istorijos kraštovaizdis. Moksliniu straipsniu rinkinys, skirtas profesorès Jüratès Kiaupienès 65-mečiui, ed. R. Šmigelskytè-Stukienè (Vilnius, 2012), pp. 295-320.

${ }^{15}$ R. Černius, 'Konfesinis ir politinis XV a. pabaigos Bažnytinès Unijos aspektas Lietuvos Didžiojoje Kunigaikštysteje', Tarp istorijos ir būtoves. Studijos prof. Edvardo Gudavičiaus 70-mečiui, ed. A. Bumblauskas, R. Petrauskas (Vilnius, 1999), pp. 215-262. 
Iosif (and opposed by the bishop of Vilnius), the other espoused by Sapiega's 'group' (and preferred by Bishop Tabor). The first sought to make Iosif a cardinal and head of an independent Unionist Church in the style of Cardinal Isidore, while the second aimed to unite Catholic and Orthodox believers practising their own rites under the control of the bishop of Vilnius, who was afraid that he would be overshadowed in the Lithuanian hierarchy by a new cardinal. In fact possession of a red hat is a red herring in this argument, since the metropolitan (that is, archbishop) of Kiev was already theoretically of higher rank than the bishop of Vilnius. As for Sapiega, it seems to be difficult to be completely sure of exactly what he sought. According to the response Pope Alexander VI gave to the scribe's supplication, it seems that Sapiega, already a Unionist (or a Catholic?), fired with devotion, founded and erected the parish Church of the Holy Ghost at Ikazn and endowed it suitably so that there would always be truly Catholic Ruthenian priests obedient to the Holy Roman Church (i.e. Unionists, not Orthodox) there to celebrate according to the practice of the Greeks and their rites, but the church had not been completed and he wishes after completion that Latin-ordained priests in communion with the Holy See also be allowed to celebrate Mass and Divine Office there. Iosif and Sapiega start from different blocks. The metropolitan was offering to reunite his Orthodox Church with Rome, while the now Catholic (Unionist?) scribe was seeking to build one church for two (Latinrite Catholic and Greek-rite Unionist) communities in his town. The issue here, as Bishop Tabor, the Pope and Dr Černius could agree is jurisdiction. A Greek-rite priest is the vicar of a Greek-rite bishop; mutatis mutandis the same applies to Latin-rite clergy. Alexander VI grants permission before the church building is complete and is consecrated in the Latin rite by the bishop of Vilnius or other suitable bishop, for all Latin and Ruthenian priests ordained in the Latin rite to celebrate Mass and Divine Office and for all Latin and Ruthenian faithful of either sex to attend those Latin-rite services. In effect the pope is Latinising Ruthenian Unionists by allowing them to attend Latin-rite services. To speed up construction work and parish endowments Alexander throws in a manus adiutrices indulgence for donors and those who visit the parish at Whitsun and Transfiguration, the Presentation of the Virgin (November 21, particularly favoured by the Orthodox), SS Peter and Paul and the 
parish feastday ${ }^{16}$. The bull allows Catholic laymen of different rites in communion with Rome to attend the same Latin-rite services led by Latin-rite priests. It is not an example of Catholic and Orthodox, or even Unionist services in the same building. Given the taxable value of the parish in 1553 (52.5 gr) it was not very well endowed ${ }^{17}$. Surely a parish church which included more than Latin-rite Catholics might be expected to be wealthier than an institution frequented by a minority of the local population.

While the Orthodox Church in the Grand Duchy continued to function separately from her Catholic sister, she was faced by organisational problems similar to those which afflicted the 'disordered' Latin diocese of Vilnius. In 1509 the Orthodox Synod (Sobor) of Vilnius was attended by Metropolitan Iosif (Bulgarinovich) of Kiev and All Rus', the bishops of Vladimir and Brest, Smolensk, Lutsk and Ostrorog, Polotsk and Vitebsk, Turov and Pinsk, Peremysl, and Kholm (the latter two sees being in Poland), the abbots of several monasteries from Kiev, Lavrashev (near Novgorodok), Slutsk, Minsk, Polotsk, Smolensk, Alšeniai, and Losk; and the archpriests (protopopy) of Vilnius, Novgorodok, Grodno, Slutsk, Markovo, Slonim and Volkovysk, among other clergy ${ }^{18}$. Almost all these towns had a Catholic bishop and or monastery or church. The meeting attempted to enlist the aid of the secular authorities to control the building of Orthodox churches and monasteries without episcopal permission. In 1522 Iona, the bishop of Turov Pinsk petitioned Sigismund the Old to confirm his brother Alexander's charter to this effect ${ }^{19}$. The synod fathers also sought to reestablish the hierarchy's control over the appointment of clergy, be they bishops or simple priests. Both of

1628 Apr. 1501, Documenta pontificum romanorum historiam Ucrainae illustrantia (1075-1953), I (1075-1700), ed. A.G. Welykyj [Analecta OSBM series II, section III] (Rome, 1953), no. 103, pp. 178-179.

171553 Vilnius diocesan tax redord, MAVBRS, F43, b. 435, fo. 3; the same sum was due from Polonka and its chantry altar - fo. $4 \mathrm{v}$. This source will be published in the appendix to Acta primae Visitationis diocesis Vilnensis anno Domini 1522 exactae sive Vilniaus kapitulos archyvo Liber IIb atkürimas (Vilnius, forthcoming). Ikazn is among Ochmański's poorest parishes. See Ochmański, Biskupstwo wileńskie, p. 104.

18 'Sobor', v bogospasaemom grade Vil'ni byvshii', Pamiatniki polemicheskoi literatury zapadnoi Rusi, I [Russkaia istoricheskaia biblioteka, IV] (St Petersburg, 1878), col. 7-8.

${ }^{19}$ Ibid., col. 11-17; 9 Feb. 1522 document, Vilnius, MAVBRS F1-385 (R. Jasas, Pergamentu katalogas (Vilnius, 1980), no. 252, p. 103. 
these issues were of pressing importance for the bishops of Vilnius too, especially Albert Tabor.

The loyalty of Vilnius Orthodox to the Lithuanian state and the shared political values of both Catholic and Orthodox subjects of the grand duke under unavoidable conditions of confessional apartheid (not to be confused with religious toleration in the more modern sense) was stamped on the city's socio-topography. The victory of Lithuanian forces over the Muscovites at Orsha in 1514 was commemorated by both the Catholic king, Sigismund the Old and his commander in chief, the Orthodox nobleman Konstantin Ostrogsky. Crossing the border of the Grand Duchy on his return from battle in September 1514 Sigismund gave orders for the endowment of a monthly mass in the first Catholic church he encountered (at Hajna) in honour of the Nativity of Our Lady, the feast on which the battle was fought. In return for a gift of land the parish priest was to sing in perpetuity these masses for the souls of the fallen ${ }^{20}$. The churches of the Grand Duchy are said to have rung their bells in celebration of the victory ${ }^{21}$.

The victory would be commemorated in the capital of the Grand Duchy itself by Prince Konstantin Ostrogsky ${ }^{22}$, who made use of the occasion to ask permission of the grand-duke king to break

${ }^{20}$ Acta Tomiciana 3, (Poznań, 1853), no. 238, p. 188: Redeuntibus nobis ex prelio, quo hostem nostrum magnum ducem Moscovie contra fedus et iurisiurandum terras nostras occupantem fudimus, cum ad pirmam nostri ritus Romani ecclesiam in Hayna applicuimus, volentes immortali Deo ac eius intemerate matri, in cuius natali tanta nobis victoria cessit, quantam presens seculum non vidit, promordia laudis et gratitudinis nostre exhibere, agrum nostrum incipiendo a domo plebanali usque ad viam, que vadit penes ecclesiam et ex alia parte plebanali usque ad fluvium illuc fluentem honorabili Andree, plebano in Hayna ac successoribus ius omnibus ad tenendum et possidendum perpetuis temporibus dedimus, donavimus et cum omni iure et proprietate immunitati ecclesiastice adscribendum concessimus, ea videlicet ratione quod dictus plebanus ac successores ipsius debebunt exnunc et in perpetuum singulis mensibus cantare aut cantari facere Missam unam de nativitate [AT has die nativitatis] gloriose Virginis Marie cum memoria occisorum, qui ex prelio adducti ibidem tumulati sunt, pro animarum eorum salute et tante victorie menoria sempiterna. In cuius rei testimonium etc. Datum [Haina, 17 Sept.1514]

${ }^{21}$ M. Čiurinskas, 'Karas ir kultūra Lietuvos Didžiojoje Kunigaikštystėje', Senoji Lietuvos literatūra, kn. 31: Istoriniai mūšiai senojoje Lietuvos raštijoje: Žalgiris ir Orša (Vilnius, 2011), pp. 127-180, here p. 145-146.

${ }^{22}$ For a brief biography of Ostrogsky, see G.M. Saganovich, Ajchynu svaiu baroniachy: Kanstantsin Asrozhski (Minsk, 1992). On his church-building activities, see K. Chodynicki, Kościót prawosławny a Rzeczpospolita Polska 1370-1632 (Warsaw, 1934), p. 80-81. 
Lithuanian law and build (or officially, to rebuild) two Orthodox churches, dedicated to the Holy Trinity and St Nicholas, in accordance with a promise he had made during the battle to present a thanks-offering for divine aid on the battlefield ${ }^{23}$. The Volynskaia

${ }^{23}$ In nomine Domini Amen. Ad perpetuam rei memoriam. Cum inter humane nature commoda nichil dignius memoria rerum gestarum ... sublimus Regum ... presencia que perpetuo memoranda sunt, ne successu temporis a mortalium dilabantur noticia sed literarum apicibus ac sigillorum ... perennare, Proinde Nos Sigismundus Dei gratia rex Polonie, Magnus dux Lituanie, Russie, Prussie Samogitieque etc ... Significamus ... quibus expedit universis et singulis, quo ... preterito lacessante nos et dominia nostra validis urg ... scelerato et ... magno Moscovie duce ad cuius reprimendos tam improbos conatur exercitum nostrum preside magnifico Constantino Ivanovicz duce Ostroviensi, castellano vilnensi et Magniducatus Lithuanie exercituum Luceoriensi et Vyniczensi Braslavieque capitaneo necnon marschalco terre Volynensis ex ... dictusque Constantinus in agro Kropidlna, in quo cum dicto hoste Moscovie ... dum erat in ... certorum consiliariorum nostrorum ceterorumque exercitus nostri magistratuus non minis religiose, qui solmeniter vovisset dum templa seu oracula in civitate nostra Vilnensi unum in honorem Sancte et individue Trinitatis, aliud vero in honorem Sancti Nicolai lapide seu latere cocto et ab ipsis fundamentis erigenda et muro consumanda sub beneplacito tamen et ratihabitacione nostra in quantum Deus Optimus Maximus nobis de dicto nephario hoste victoriam contulisset gentesque ipsius non minus efferatas quam numerosissimas in manibus nostris dedisset. Qua ... re, quod felix faustumque sit, secuta hoc est dicti hoste per nos ad intervectionem profugato tam sepedictus Constantinus qua etiam dicti consiliarii humiliter cum ... nobis supplicarunt, quatenis ipsis predicti noti liberam exequucionem permitteremus. Et quia lege sancta et evangelica erudiri videmur ut et voveamus et reddamus vota nostra Deo predictis illorum de consilio consiliariorum nostrorum supplicacionibus ... iustis et rationabilibus benigniter annuen supradictas ecclesias Sancte Trinitatis in colle vici quo itur ad portam vie versus Miednyky in ubi antiquus ... cum monasterio eiusdem tituli ritus ... erat ex ligno effectum. Sancti vero Nicolai quam magnum appellant ... muro consumanda. In ipsisque omnia divina officia ritu ipsorum greco pagi ... duximus permittenda presentibusque permittimus ut plenam ... nostra admissionis et consensus non obstantibus constitucionibus consuetudinibusque in contrarium disponens, quibus pro hac vice derogamus: perpetue ... harum quibus sigillum nostrum quo tanquam Magnus dux Lituanie utimur est subappensum testimonio litterarum. Datum Vilne feria quinta ipso die Sancti Andree apostoli anno Domini millesimo quingentesimo quarto decimo Regni vero nostri anno octavo, presentibus ibidem magnificis ac generosis Nicolao Nicolai Radivil palatino Vilnensi et Magniducatus Lituanie cancellario, Gregorio Ostykowycz palatino et Stanislao castellano Troczensibus capitaneoque || Samogitarum ... Alberto Gaschtoldo poloczensi, Ioanne de Zabrzezie Novohrodensi ... Sopiha Transnarvensi et secretario nostro palatinis, Joanne Mykolaiowicz Radivid Magniducatus Lithuanie marschalco et capitaneo Slonymensi, Niemyra Hrymalowicz Mielniczensi, Georgio Hlynicz Berestinensi capitaneis nostris et alys quam plurimis consiliarys, aulicis et marsclacis nostris sinceris et fidelibus nostris ... per manus venerabilis Stanislai Tharlo de Sczekarzowicze Cracoviensis, Wladislaviensis, Sandomiriensis ecclesiarum 
Kratkaia Letopis' redaction of the Lithuanian Chronicle contains an extended account of the battle which notes how the god-fearing hetman prayed in the Church of the Holy Trinity and St Nicholas at Orsha before combat began ${ }^{24}$. A few years earlier Ostrogsky had used his good favour with the monarch to rebuild the Church of the Most Pure Virgin which still stands by the River Vilnelè at the entrance to the suburb of Užupis ${ }^{25}$.

\section{Micro-historical contacts}

While at a high level of society the idea of Church Unity was attractive politically and even official prohibitions on the building of Orthodox churches could be overlooked for reasons of patriotism and personal favour, the thought that such a union would open the doors not only of the cathedral but also of the high offices of state to a wider section of gentry and clergy was intimidating for Catholic lords be they spiritual or temporal. However, in the lives of more ordinary people contacts between the two (three) communities were unavoidable. Most of our evidence of such relations comes unsurprisingly from a family milieu and it involves property. The records of church foundations and consistory courts (in Lutsk and Gniezno) help shed light on such matters. In 1457 three Ruthenian brothers Jan, Stanisław-Hryńko and Haczko of Wirowo joined Stanisław of Nieczęcy, a village $7 \mathrm{~km}$ to the north-east of Sokołow Podlaski in the foundation of a chapel to the Immaculate Conception and St Dorothy. The first two brothers were called neophites (indeed Hrynko may have been rebaptised as Stanisław), while the third was described as scismaticus or Orthodox ${ }^{26}$. This is a good example both of the

canonici, secretary nostri. Sigismundus Rex. (a genuine parchment with a seal of the Grand Duchy attached, according to the editor). Sobranie drevnikh gramot $i$ aktov gorodov Vil'ny... Chast' II (Vilnius, 1843), no. 6, p. 13-15.

${ }^{24}$ Polnoe sobranie russkikh letopisei, 35 (Moscow, 1980), p. 125-127. The manuscript came from the Suprasl Monastery and dates from the first half of the sixteenth century (ibid., p. 10). The author of the account makes use of.

${ }^{25}$ On 4 July 1525 Ostrogsky and his wife Tatiana Holszańska donated their estate at Sesuolai to this church in return for a panakhida (memorial prayers) for their souls on Friday evenings and Saturday mornings at two altars near the doors Sobranie drevnikh gramot, no. 171, pp. 89-93. For an account of the architectural style of the building, see J. Monkevičius, Lietuvos architektūros istorija, I: Nuo seniausiu laiku iki XVII a. vidurio (Vilnius, 1987), p. 153.

${ }^{26}$ Jaszczołt, 'Fundacje kościelne', p. 34. 
latinisation of Orthodox territory (Podlasie) and of family solidarity in ecclesiastical foundations despite confessional differences.

From the diocese of Vilnius we learn that in 1514 a patron of the royal foundation of the Catholic Church of the Nativity of the Virgin in Cholchlo, Marina Vladyczanka, realising that she had no kinsman in communion with the Roman Church into the hands of which she would entrust her soul after death, who would take care of her soul, decided to grant a tithe to the parish priest which her heirs even if they be Orthodox would be obliged to pay on pain of damnation ${ }^{27}$. It is clear that family ties were not broken by confessional division and that although schismatics be regarded as ideological aliens they were still susceptible to the same ultimate threat, fear of which could ensure their cooperation with the conditions of a Catholic emolument, namely eternal damnation.

In 1498 Orthodox noblemen and tenants of the duke of Slutsk and Bishop Tabor, along with the sub-chamberlain of the bishop of Vilnius, Fr Thomas of Sadecz, witnessed the will of Jan-Iwaszko Cholchistewicz of Khorostovo in the Duchy of Mstislavl. JanIwaszko asked to be buried in the Bernardine church in Vilnius and bequeathed goods in Khrostovo including a fox-fur coat to the local pop, a red tunic to the diak, Miszko, along with 120 groats for services rendered, and hiveland to the Orthodox parish church of the Blessed Virgin Mary itself. The now Catholic landowner did not forget his Orthodox connections far from the capital ${ }^{28}$.

An Orthodox believer might go to confession to a Catholic priest, even though this was not permitted. One 1476 case from the Lutsk consistory court refers to Peter the Chaplain, curate of Wistyczi who boasted to a servant woman, Kulincza, while riding home with a

27 ...quod nullum consanguineum habeo in Fide Catholica, qui esset sub obedientia Romane Ecclesie, cui deberem in manus commendare animam meam post mortem meam, in quibus confidere debeam, aut qui pro anima mea curam haberet, volens certitudinem indubiam habere, do et approprio ac incorporo decimam de omni grano de seminibus camporum et hortorum meorum, nihil excipiendo, in curia mea Cierniewo nuncupata, mei veri et legitimi patrimonÿ ecclesie tituli Virginis Gloriose Marie Nativitatis in Chochlo lego et inscribo honorabili Stanislao plebano moderno inibidem suisque posteris curatis eviterneque et in evum inscribo et quicunque consanguinei Catholici et schismatici ritus dictam curiam possidebunt iure hereditario successione propinquitatis dictas decimas de eadem curia dent, tradant realiter et cum effectu sub damnatione eorum dare.

${ }^{28} K D K D W$, no. 453 , p. XX. It would be a mistake to think that a bequest to an Orthodox institution, as in this case, signifies that the donor was (still) - cf. Trimonienè, 'Katalikų Bažnyčios politika', p. 336. 
gentleman, Andreas Ostromieczowicz, that he had heard the confession of her Orthodox sister Margaret. One of Andreas' servants confirmed this claim while a third witness, the Wistyczi ministerial, Stanisław, Peter's rival, remembered seeing a head covering in the curate's bed, while the parish priest was away. Even though in a different case Peter had to answer to the court for sexual misconduct with other women, this case bore the rubric de confessione ${ }^{29}$.

The difference between Catholic and Orthodox jurisdictions could be abused by sly litigants, even though such ruses were not guaranteed to succeed. In 1485 the parish priest of Bielsk, Stanisław, sued a parishioner over non-payment of a tithe. The man claimed that his manor had been given to an Orthodox man by Grand Duke Vytautas and therefore it should not be treated as though it were Catholic, despite the fact that several witnesses asserted that its noble owners had always paid a tithe to the priest in Bielsk ${ }^{30}$. A similar story is recorded involving the parish priest of Hadniowo, Andrew, and a nobleman over payment of tithe to the local church, based on the evidence of a charter of exemption originally given by Vytautas to a 'schismatic' named Szreba ${ }^{31}$. An Orthodox factor might work for a Catholic landlord but that of course would not save him from prosecution in a Catholic consistory court ${ }^{32}$.

29 The Lutsk (Janów Podlaski) Consistory court records, Book 1, Siedlce, Archiwum Diecezjalne w Siedlcach [ADS] D1, fo 40: Testes inducti ex parte honorabilis Nicolai plebani de Visticze ad instanciam discreti capellani de ibidem et hoc de confessione scismatice.

${ }^{30}$ ADS D1, fo 83v., In causa plebani Byelsky pro decimis testes: ... Tercius testis providus Nicolaus Starizab deposuit: dicti nobiles per dominum Stromilo in ipsa hereditate, que fuit ruthenica, in qua nunc sedent, circa Witholdum bone memorie. Tandem dum prenominatus magnus dux llithfanie obligavit eos, quod $i$ equum darent de ipsa terra, sed quia non potuerunt ex defectu successoris vendiderunt partem terre huius ruthenis et aneys equis pro tribus sexagenis dederunt Witholdo tunc ruthenus ille Olenk terram illam noluerunt dare decimam quibus rex precepit, quod veluti lathinorum terre essent, decimam.

${ }^{31}$ ADS D1, fo $13 \mathrm{v}$.

32 Archiwum Archidiecezjalne w Gnieźnie [AAG] Acta Cons. C3 fo 316: Sententia providi Olechno factoris in Trokyelye appellantis et honorabilis Leonardi mansionarii ecclesie cathedralis vilnensis appellati, $1 \mathrm{Feb}$. 1524. Olechno to pay costs. Trokele or Novy Dvor, Lida district, $10 \mathrm{~km}$ n.e. of Zhirmuny, belonged to the Jagintaičiai-Rimvydaičiai family, cf. $K D K D W$, no. 212. Two cathedral mansionaries named Leonard are known from 1537 and 1539, see V. Ališauskas, T. Jaszczołt, L. Jovaiša, M. Paknys, Lietuvos kataliku dvasininkai XIV-XVI a. [Bažnyčios Istorijos Studijos II] (Vilnius, 2009), no. 1188, 1189, p. 216. It is not clear whether one of these men is meant here, or indeed a third Leonard. 
Orthodox testators used Catholic arengae in their wills (such as the famous quotation from Scripture, ne est chelovek peven odno smerti, anitezh jej nepeven odno na den smerti chasu) and found chantry altars in Orthodox churches (as in the case of Fedor Janushevich, former lord lieutenant of Vladimir, who in 1507 left endowments for a chantry in the Vilnius Prechistensky Sobor ${ }^{33}$. These are examples of cultural, not ideological imitation.

In Vilnius Catholic and Orthodox burghers shared equal rights after 1432. The town had two burgomasters, one Catholic, the other Orthodox. From the late 1450s apparently Orthodox burghers had their own fraternity, the furriers' guild, organised along the lines of Catholic fraternities existing in the town from the 1420s at both the parish church and the Franciscan friary. While it is true that Orthodox guilds existed in Lviv from around 1439, it seems more likely that in this respect Vilnius Orthodox burghers imitated their Catholic neighbours rather than importing a Catholic habit from imitators of the custom in Crown Rus'. Fraternity members organised memorial feasts for deceased members, and agreed to settle disputes within the guild rather than suing in the magistrates' court $^{34}$.

The case of the parish of Polonka in the Vilnius diocese is an interesting case of Catholic-Orthodox convivencia far from the capital. This town to the south east of Novgorodok was home to both communities. The Orthodox had their own sinagoga rutenica, while a Catholic Church of the Visitation, SS Peter and Paul and St George was founded in 1437 by a nobleman Petraus Raczko Strocewicz. By the end of the century the main patron of the living was the lord lieutenant of Smolensk, Stanislovas Hlebavicius, while members of the local gentry set up a fraternity for male and female parishioners of all classes. Donations to the fraternity were witnessed by the local Orthodox priest (Pop Many) and Orthodox neighbours such as Olechno, who is described as schismaticus, qui

33 MAVBRS F1-45 (26 Apr. 1507); Jasas, Pergamentu katalogas, No 171, p. 74.

${ }^{34}$ No. original charter survives for this guild. The earliest extant document dates to 31 Dec. 1538, where Sigismund the Old states that the guild had existed for eighty years. See Chodynicki, Kościót prawosławny, pp. 177-181. Over the centuries town guilds would open membership to burghers and gentry of both Roman and Byzantine confessions. 
morabatur in Hyrikowczyzna ${ }^{35}$. The Catholic priest was given land to build an inn on the square in front of the Orthodox Church ${ }^{36}$. It is interesting that after the 1596 Union of Brest which established the Uniate Church in the Grand Duchy of Lithuania and Crown Rus' the Catholic (Latin-Rite) parish church was taken over by the Uniates; the Orthodox parish also continued to exist in the town where antagonism between the two communities (in the eighteenth century) led to the desecration of St Peter's, and the desecration of graves of its Hlebavčius Catholic patrons. In 1502 one Catholic parishioner revealed in his will how relevant the issue of Church Union was, as he stressed that he would leave this world in union with the Roman Church - in unitate fidei sancte romane ecclesie de hac vita decedo. ${ }^{37}$ In the broader context of the Latinisation of Ruthenian lands in the Grand Duchy (modern Belarus and Podlasie) the Polonka case is of particular interest. The Hlebavičiai established their status as servants of the grand duke. Stanislovas Hlebavičius was a Ruthenian specialist. He served as envoy to Muscovy and took part in negotiatons over the marriage of Grand Duke Alexander and Elena Ivanovna of Moscow. He later served in the grand duchess' court and became lord lieutenant of Polotsk. His wife, Zofia Korczewska, was the daughter of a Podlasie gentleman and through her he gained land and ecclesiastical advowson in Mordy. Their daughter Elžbieta married the grand duke's Ruthenian scribe, Jonas Sapiega, of whom we have already

${ }^{35}$ Many - KDKDW no. 506 , p. 616 , no. 516 , p. 622 , no. 534 , p. 634 ; Olechno no. 573 , p. $691-692$.

${ }^{36}$ MAVBRS, F43, b. 204, fo 71: In nomine Domini amen. Anno Domini millesimo quingentesimo vigesimo nono, Ego Joannes Hlebowicz palatinides Polocensis haeresque in Polonka recognosco per has literas nostras sub sigillo meo, quia pro stagno, quem legavit pater meus dominus Stanislaus Hlebowicz palatinus Polocensis ecclesiae in Polonka, do et ascribo terram, quae vocatur Latunowczyna medii semitii, ubi manet Klimowicz Czyniochwiej cum omnibus et singulis proventibus, agris, pratis, gaiis ut in se terra habetur et omnibus utilitatibus, nihil pro se remanendo neque usurpando et aream in eadem Polonka pro taberna libera edificanda inter Kusmam et Matyey in circulo penes ecclesiam scismaticam; quam tabernam solus plebans debet construere et hoc perpetue et in aevum honorabili domino Alberto plebano pro tunc existenti in eadem Polonka. For a separate study of the parish of Polonka in the 15-16 centuries see S.C. Rowell, 'Parapijos dangaus ir žemès globejju vaidmuo bendruomenès identiteto formavimesi - Polonkos pavyzdys' (forthcoming).

${ }^{37} \mathrm{KDKDW}$, no. 538 , p. 635-636. 
heard and who subsequently became lord lieutennat of Podlasie, where marriage had made him an ecclesiastical patron. ${ }^{38}$

In conclusion we may say that the position of the Orthodox Church in the Grand Duchy of Lithuania was at the same time both solid and ambiguous. While political moves were made from the fourteenth century to subject the Metropolitanate of Kiev and All Rus' to the will of the monarch either by supporting an Orthodox ('schismatic') ecclesiastical hierarchy separate from candidates supported by the Orthodox of the Grand Duchy of Muscovy, or by engineering a Unionist Church in communion with Rome, both policies caused as many problems as potentially they might solve. Neither the Catholic palatines nor the Latin prelates of Lithuania welcomed Orthodox or even Unionist competitors. However, on a micro-political level both in Vilnius and in the country at large the Orthodox Church in Lithuania was clearly well-integrated into public life and in tune with Catholic devotional traditions (such as the building of hospices and chantry altars and the formation of parish fraternities). The crude nineteenth-century imperial equivalence of Orthodoxy with Russia and Russia with Muscovy is virtually irrelevant to the history of the early-modern Grand Duchy (where Orthodoxy was associated primarily with Schism). Catholics also came to venerate icons (at Aušros Vartai or Our Lady of Trakai); schismatic kin were expected to protect the ecclesiastical foundations of childless Catholic benefactors and Catholic landowners could build or endow both Catholic and Orthodox churches side by side in Lithuanian towns (such as Anykščiai or Drohiczyn). Even so, to prove his ideological zeal Bishop Tabor commissioned an anti-Ruthenian treatise from his university idol, Jan Sakran, in 1501 while theoretically encouraging the Unionist community in the Grand Duchy. The duality is illustrated best perhaps by a dispute in 1512 between Stanislovas Kiška (Stanislaw Kiszka) lord lieutenant of Grodno and the starosta of Žemaitija, Stanilovas Kęsgaila over the right of advowson to the Catholic parish church at Deltuva. During the appeal case heard before the Gniezno metropolitan consistory court lawyers on both sides agreed to send a messenger back to Vilnius to bring materials from the Vilnius consistory court. When Frederick (hardly an Orthodox name!) of Betygola returned to Gniezno with the sealed

${ }^{38}$ T. Jaszczołt, 'Osadnictwo lewobrzeżnej części ziemi drohickiej w XV i na początku XVI w. - okolice Sokołowa, Węgrowa i Mord’, Sokołow Podlaski. Dzieje miasta i okolic, ed. G. Ryzewski (Białystok-Sokołow Podlaski, 2006), p. 216. 
documents the papers were acknowledged as genuine and submitted to the court. However, when the unsealed evidence ran contrary to the arguments of Kiška's case, his lawyer demanded the material be dismissed since the messenger was a Ruthenian and therefore (sic!) excommunicate. The court authorities responded that whether the messenger were a Ruthenian or any other pagan, the seals on the documents had been recognised by both sides as genuine, and so remained admissible. ${ }^{39}$

Author Details

Professor S.C. Rowell is senior research associate at the Department of History of the Grand Duchy of Lithuania, Lithuanian Institute of History. His main scholarly interests are late medieval history of the Grand Duchy of Lithuania and Kingdom of Poland.

Address: Lithuanian Institute of History, Kražių g. 5, Vilnius LT-01108

\section{PRIIMTINAS KIEKVIENO PAGONIO DOKUMENTAS. LDK KATALIKŲ IR STAČIATIKIŲ SANTYKIŲ VÉLYVESNIAISIAIS VIDURAMŽIAIS APŽVALGA}

Santrauka

\section{S.C. ROWELL}

Straipsnyje aptariami ịvairūs 15 a.-16 a. pr. LDK katalikų ir stačiatikių unitų santykių aspektai tiek Vilniuje, tiek šalies gilumoje. Nors stačiatikių ir Romos katalikų Bažnyčių suvienijimas buvo aktualus politinis tikslas, tačiau katalikų ponai tiek Bažnyčioje, tiek Ponų taryboje nebuvo linkę pasitikèti galimais konkurentais stačiatikiais. Florencijos unijos sąlygas prièmę rusènai susidūrè su abiejų šalių priešiškumu. Vis dẻlto išlikusi bažnytinių teismų ir parapijų suteikčių medžiaga rodo, kad dèl šeimos arba bendruomenès interesų abiejų konfesijų žmonès kartais sugebėdavo bendradarbiauti.

${ }^{39}$ AAG, Acta Consistorii A (Acta Acticantium) 78 fos 140v, 147, 155, 165, 169, 172-174; A Con A 79, fos 3: Jeremias procurator Grodnensis patroni et collatoris parrochialis ecclesie in Dziewolthowa ... allegans illa omnia non valere neque illis fidem adhiberi quia idem Fredericus mentita fide existens Rutenus et propter hoc excommunicatus... Andreas [lawyer for Stanislovas of Žemaitija] respondit generaliter nec obstat quod allegat procurator exadverso, quam Rutenus vel alter paganus sit portitor literarum, cum ipse rotulus sit sigillatus et clausus, quem habuit pro recognito Jeremias. [Date of session, 14 Jan. 1513]. 